\title{
US ecological survey runs political gauntlet
}

Washington. The US National Biological Survey (NBS), proposed last year by the Secretary of the Interior, Bruce Babbitt, as the government's principal agency for ecological research, has run into unexpectedly strong opposition from anti-environmental forces in Congress.

A bill setting up the NBS was passed by the House of Representatives in October. But in the process it became the target of heated attacks by lawmakers representing private property owners, and similar pressure is expected when the bill is debated in the Senate within the next few months.

The NBS has been promoted by Babbitt as a non-political, rigorously scientific agency. But its opponents fear that data from a nationwide biological survey might be used to set aside large tracts of land as nature reserves.

The congressional attacks are part of a broader campaign by property owners to oppose any environmental measures that restrict land development without compensating the owners of the land by arguing that this is an unconstitutional appropriation of private property. The NBS debate in the House was the first opportunity to test this argument, which is also likely to be used against the Endangered Species Act, as well as legislation to protect wetlands.

An amendment to the House NBS bill proposed by Billy Tauzin (Democrat, Loui- siana) would have required the government to compensate any property owner whose land lost value as a result of findings by the NBS.

The amendment was defeated, but only by the use of a legislative point of order that ruled it to be irrelevant to the debate. There is no such rule in the Senate, so this argument will almost certainly arise again there. "Clearly it's going to be a major fight," says Bruce Stein of the Nature Conservancy.

House opponents did succeed in passing an amendment requiring NBS employees or others working for the survey to obtain written permission from all property owners before conducting research on their land.

The standard procedure for this kind of fieldwork in the past has been to respect any existing state trespass laws. The new requirement will not prevent NBS from doing its research, says Stein, but it will significantly slow down the survey's ability to do work on private lands.

A more serious obstruction to the agency's work would be another amendment passed by the House which prohibits the NBS from accepting the services of volunteers. Biological surveys traditionally depend on fieldwork conducted not only by university researchers and museums, but

\section{Audit confirms big is not always beautiful}

London. The effectiveness of Britain's investment in wind energy research has been undermined by the influence of a single potential customer, the Central Electricity Generating Board (CEGB), according to a report published last week by the National Audit Office (NAO), the government watchdog.

The CEGB's anticipated needs appeared to favour large-scale megawatt size machines as the most practical options. But social demand - as the late economist E. F. Schumacher predicted in his book Small is Beautiful - has proved greater for medium- and small-scale turbines.

One result appears to be that only about 20 per cent of the wind turbines installed in Britain are manufactured domestically, and exports are also small. In comparison, all wind turbines installed on Danish wind farms are manufactured in Denmark, and 60 per cent of those in the United States are built by US manufacturers.

Up to 1987 , the main focus of funding for research and development was on largescale machines. Projects covered by such funding included the construction of one of the world's largest wind turbines, a 3-MW machine built on the island of Orkney which started operation in 1987.

In practice, however, large-scale machines have proved to be uneconomic, and the market for them (even from electricity utilities) has remained small in comparison to that for medium-sized and small wind turbine machines.

The former have been the main focus of the Department of Energy's wind energy programme only since 1987 ; and according to the NAO report, appeals for funding from a number of small wind turbine manufacturers serving niche markets in the United Kingdom have been virtually ignored.

Department officials told NAO investigators that they considered support for such initiatives would be more appropriate from programmes designed to promote small businesses.

Overall, the NAO report says that the department's methods for assessing the potential of different renewable energy sources is "soundly based".

But it also concludes that the earlier influence of the nationalized electricity industry as the main customer "led to a few projects and programmes receiving a large share of the $£ 340$ million spent”.

\section{IMAGE \\ UNAVAILABLE FOR COPYRIGHT REASONS}

also by conservation groups and amateur naturalists.

A report last year by the National Research Council recommended that the NBS conduct its mission in partnership with other existing groups. Peter Raven of the Missouri Botanical Garden in St Louis, who chaired the NRC study, describes the prohibition against using volunteers as "strange", and adds: "I can't see any way that it could be operational."

If the amendment is allowed by the Senate to stand, the NBS "would be the only community effort in the United States that prohibited the use of volunteers," says Raven. NBS supporters are optimistic that the House amendment will be overturned -or at least watered down - in the final legislation officially authorizing the existence of the new agency.

So far, the lack of such legislation has no real impact on the work of the NBS. The agency established by Babbitt's order last November has received $\$ 163$ million from Congress for this year's operations.

A new director, expected to be Ronald Pulliam of the University of Georgia, a former president of the Ecological Society of America, should be in post soon. The staff is already short-listing areas for the first pilot studies, which will include the Florida Everglades and other regions of ecological and political interest.

But without the authorizing legislation, continued funding for the NBS - and its very existence - are precarious. Congress appropriated money this year on the understanding that such legislation would soon be passed, and as one congressional staff member says, "you don't like to fund money for things that aren't authorized."

Senate hearings on the NBS should begin this spring, and supporters hope that final legislation will pass this summer, before the next funding cycle begins.

In the meantime, says Thomas Lovejoy of the Smithsonian Institution, who advised Babbitt on setting up the new agency, "what all of us would like to do is just build a record with the survey showing that it's not a threat."

Tony Reichhardt 